\title{
The Effect of Salinity and Nutrient Load on the Ecosystems of Selected Lakes in the South of Siberia
}

\author{
Egor S. Zadereev ${ }^{\mathrm{a}, \mathrm{b} *}$, Anton V. Drobotov ${ }^{\mathrm{a}}$, \\ Alexander P. Tolomeeva,b, Olesya V. Anishchenko ${ }^{a}$, \\ Olesya E. Yolgina ${ }^{a, b}$ and Anzhelika A. Kolmakova ${ }^{a}$ \\ ${ }^{a}$ Institute of Biophysics \\ Krasnoyarsk Research Center SB RAS \\ Krasnoyarsk, Russian Federation \\ ${ }^{b}$ Siberian Federal University \\ Krasnoyarsk, Russian Federation
}

\begin{abstract}
Salinity largely determines the species diversity and structure of the food web in lake ecosystems. Many studies have been focused on the salinity tolerance of various plankton species. There are fewer studies investigating the modifications in the food web interactions under the effect of salinity. An appropriate system for such studies is closely located lakes of different salinity. We took samples during the summer stratification and analyzed the physicochemical and biological characteristics of 20 lakes (salinity 0.1-35 g/l) in southern Siberia in order to provide general description of this system and to test a number of hypotheses about the effect of salinity on the structure of the food web. The analysis revealed two key factors structuring ecosystems of the studied lakes. The species composition of zooplankton was determined by salinity, with a decrease in the number of species and the transformation of the community from a diverse community of zooplankton (salinity up to $3 \mathrm{~g} / \mathrm{l})$ to the dominance of large daphnia (3-8 g/l), copepods ( $>8 \mathrm{~g} / \mathrm{l})$, small cladocerans and rotifers (20-30 g/l), and Artemia (>30 g/l). The top predator (fish) was eliminated at salinity above 10 $\mathrm{g} / \mathrm{l}$. The biomass of zooplankton did not depend on salinity, but significantly increased in lakes with an increased nutrient load. The nutrient load also had a significant effect on the concentration of total phosphorus, turbidity and transparency of water, and the concentration of chlorophyll "a". Thus, we recorded the structuring effect of the nutrient load (bottom-up control) on the biomass of the trophic levels and the parameters of water transparency, while salinity transformed the trophic chain from the
\end{abstract}

(C) Siberian Federal University. All rights reserved

This work is licensed under a Creative Commons Attribution-NonCommercial 4.0 International License (CC BY-NC 4.0).

* Corresponding author E-mail address: egor@ibp.ru

ORCID: 0000-0003-2366-8604 (Zadereev E.); 0000-0002-9124-4566 (Tolomeev A.); 0000-0002-1976-599X (Anishchenko O.) 
top, leading to the disappearance of fish and a change in the dominant species of zooplankton. At the same time, salinity did not affect the biomass of the trophic levels. In order to detect top-down effects in the ecosystems of saline lakes, it is necessary to perform a comparative analysis of the seasonal dynamics of ecosystems of lakes with different salinity.

Keywords: phytoplankton, zooplankton, top-down effects, saline lakes, bottom-up control, food web.

Acknowledgements. The study was supported by Krasnoyarsk Regional Scientific Foundation, The Governance of Krasnoyarsk Krai and Russian Foundation for Basic Research, Grant No. 19-44-240010. The authors are grateful to two anonymous reviewers for their valuable comments.

Citation: Zadereev E.S., Drobotov A.V., Tolomeev A.P., Anishchenko O.V., Yolgina O.E., Kolmakova A.A. The effect of salinity and nutrient load on the ecosystems of selected lakes in the south of Siberia. J. Sib. Fed. Univ. Biol., 2021, 14(2), 133-153. DOI: 10.17516/1997-1389-0343

\title{
Влияние солености и биогенной нагрузки на экосистемы ряда озер юга Сибири
}

\author{
Е.С. Задереев ${ }^{\mathrm{a}, \sigma}$, А.В. Дроботов ${ }^{\mathrm{a}}$, А. П. Толомеев ${ }^{\mathrm{a}, \boldsymbol{\sigma}}$, \\ О. В. Анищенко ${ }^{a}$, О.Е. Ёлгина ${ }^{\text {a, }}$, А. А. Колмакова ${ }^{a}$ \\ ${ }^{a}$ Институт биофизики \\ ФИЦ КНЦ СО РАН \\ Российская Федеращия, Красноярск \\ ${ }^{\sigma}$ Сибирский федеральнылй университет \\ Российская Федерация, Красноярск
}

\begin{abstract}
Аннотация. Соленость во многом определяет видовое разнообразие и структуру трофической цепи озерных экосистем. Большое количество работ было посвящено исследованию толерантности различных видов планктона к солености. Последствия модификаций звеньев трофической цепи для функционирования экосистемы рассматривают реже. Удобным объектом для таких исследований являются близкорасположенные озера различной солености. Мы провели отбор проб в период летней стратификации и проанализировали физико-химические и биологические характеристики 20 озер (общее количество растворенных солей от 0,1 до 35 г/л) на юге Сибири с целью общего описания экосистем и проверки ряда гипотез о влиянии солености на структуру трофической цепи. Анализ выявил два ключевых фактора, оказывающих влияние на экосистемы исследованных озер. Видовой состав зоопланктона определялся соленостью с уменьшением числа видов и трансформацией сообщества от разнообразного сообщества зоопланктона (солености до 3 г/л) к доминированию крупных дафний (3-8 г/л), копепод (> 8 г/л), мелких ветвистоусых и коловраток (20-30 г/л) и артемий (> 30 г/л). Верхнее трофическое звено (рыбы) элиминировалось при солености выше 10 г/л. Биомасса зоопланктона не зависела от солености, но возрастала в озерах с увеличенной биогенной нагрузкой. Биогенная нагрузка также достоверно влияла


на содержание общего фосфора в воде, мутность и прозрачность воды, концентрацию хлорофилла «а». Таким образом, зафиксирован структурирующий эффект биогенной нагрузки (bottomup-контроль) на биомассу звеньев трофической цепи и показатели прозрачности воды, тогда как соленость трансформировала трофическую цепочку сверху, приводя к исчезновению рыб и смене доминирующих видов зоопланктона. При этом соленость не влияла на биомассу звеньев трофической цепи. По всей видимости, чтобы обнаружить каскадные эффекты в экосистемах соленых озер, требуется провести сравнительный анализ сезонных динамик развития экосистем озер различной солености.

Ключевые слова: фитопланктон, зоопланктон, каскадные эффекты, биогенный контроль, соленые озера, трофическая цепь.

Благодарности. Работа выполнена при поддержке гранта Краевого фонда науки, Правительства Красноярского края и Российского фонда фундаментальных исследований № 19-44-240010. Авторы благодарны двум анонимным рецензентам за ценные замечания.

Цитирование: Задереев, Е.С. Влияние солености и биогенной нагрузки на экосистемы ряда озер юга Сибири / Е. С. Задереев, А. В. Дроботов, А.П. Толомеев, О. В. Анищенко, О. Е. Ёлгина, А. А. Колмакова // Журн. Сиб. федер. унта. Биология, 2021. 14(2). С. 133-153. DOI: 10.17516/1997-1389-0343

\section{Введение}

Соленые озера находятся под постоянным давлением различных факторов окружающей среды, в том числе таких, как изменение климата и антропогенные воздействия (Zadereev et al., 2020). Действие этих факторов приводит к вариациям уровня воды и солености, что влияет на функционирование экосистем соленых озер. Примеры таких событий наблюдали и в прошлом, так как изменчивость уровня воды, солености и связанные с этим перестройки в структуре трофической цепи экосистем соленых озер можно считать характерными чертами этих природных объектов (например, Langbein, 1961; Comín et al., 1992). Однако в настоящее время наблюдается беспрецедентное ускорение этих процессов. При этом ученые отмечают отсутствие единообразного тренда в изменении солености в озерах для разных регионов мира (Gozlan et al., 2019; Zadereev et al., 2020). Резкие изменения солености приводят к потере биоразнообразия, сказываются на способности экосистем предоставлять экосистемные услуги, создают проблемы для заинтересованных водопользователей (Williams, 2002). В критических ситуациях, например в случае Аральского моря, речь идет об экологических катастрофах (Micklin, 2007). В связи с этим крайне актуально понимать основные закономерности реакции экосистем озер на изменение солености.

Зоопланктон является одним из ключевых звеньев трофической цепи озерных экосистем. С одной стороны, его развитие ограничено прессом верхнего трофического уровня (рыб и других хищников), с другой - он зависит от биомассы и качественного состава нижнего трофического уровня (фитопланктона). В результате сообщество зоопланктона и его структурные особенности отражают важность и относительный вклад восходящего (bottom-up) и нисходящего (top-down) контроля в водной экосистеме (Jeppesen et al., 2011). Современные исследования показали, 
что с ростом солености в структуре сообщества зоопланктона происходят резкие изменения, часто они наблюдаются при достижении определенных пороговых значений солености, например когда в экосистеме исчезает рыба (Lin et al., 2017). Остается не до конца понятным, как на такие изменения влияют другие факторы, например содержание биогенных элементов, доступность пищи, температура и проч.

Озера разного размера, глубины и солености, расположенные в непосредственной близости друг от друга, можно рассматривать в качестве идеальной естественной лаборатории для исследования взаимодействий между компонентами трофической цепи. Подобные системы озер можно найти в различных регионах мира (например, в Сибири, Тибете, Турции, Казахстане, Крыму и других местах). В последнее время этим «природным лабораториям» уделяется большое внимание, поскольку практически одновременный отбор проб из таких озер дает уникальную информацию о влиянии солености на функционирование озерных экосистем (например, Lin et al., 2017; Shadrin, Anufriieva, 2020; Afonina and Tashlykova, 2020).

На юге Сибири, в частности на территории Красноярского края и Республики Хакасия, расположены десятки озер разной солености, различающиеся размером и глубиной, экологической и рекреационной ценностью (Parnachev and Degermendzhy, 2002). Некоторые из этих водоемов, например озеро Шира, широко известны как лечебные озера, десятки мелких озер зачастую используются для дикого отдыха или как места выпаса скота. Подробное описание физико-химических и экологических свойств некоторых озер, расположенных на территории Хакасии, было выполнено в обзорных работах середины и конца прошлого века и в начале двухтысяч- ных (Гидроминеральные ресурсы района озера Шира, 1959; Басков и др., 1972; Кусковский, Кривошеев, 1989; Гусева и др., 2012). Однако эти описания часто были фрагментарны, фокусировались на химических свойствах воды (Гусева и др., 2012) или группировали озера на основе их географического расположения (Parnachev and Degermendzhy, 2002). Учитывая изменчивость уровня воды и солености во многих озерах, общие описания со временем теряют актуальность. Лишь о некоторых озерах, таких как Шира, Шунет, Учум, опубликованы серии статей с детальным описанием физико-химических характеристик озер, структуры, сезонной и межгодовой динамик развития экосистем (Degermendzhy et al., 2010; Rogozin et al., 2017b; Rogozin et al., 2018). При этом в литературе не представлены результаты одновременных наблюдений за экосистемами озер, ранжированных в градиенте солености, что может быть крайне важным для анализа влияния этого фактора на их функционирование.

Учитывая, что подобные объекты представляют огромный интерес для исследования совместного действия солености и других биотических и абиотических факторов на функционирование озерных экосистем, в данной работе приводим общее описание выбранного нами ряда озер по градиенту солености, которые могут быть использованы для решения различных теоретических и прикладных задач лимнологии. Кроме того, на полученном массиве данных мы проверили ряд современных гипотез о влиянии солености на структуру трофической цепи в озерных экосистемах: 1) с ростом солености уменьшается количество видов зоопланктона и сложность трофической цепи; 2) перестройка видового состава и структуры трофической цепи происходит скачкообразно, при критических уровнях солености; 3) смена 
функциональных групп зоопланктона, различающихся типом питания, с изменением солености приводит к изменениям в составе фитопланктона.

\section{Материалы и методы}

Объектами исследования были озера Белё (Малое и Большое), Шира, Иткуль, Власьево, Тус, Джирим, Утичьи 1 и 3, Шунет, Матарак, Чаласколь, Киприно, Фыркал, Слабительное, Красненькие 2 и 3, Красненькое, Сухое (Чебаково-Балахтинская впадина, Республика Хакасия) и озеро Учум (Красноярский край) (рис. 1).
Измерения и отбор проб проводили с 17 по 21 июля 2019 г., на небольших озеpax - в центре озера, который определяли по GPS-навигатору с загруженной картой озеpa, на крупных озерах - на расстоянии 1 км от берега. Координаты отбора проб и общие характеристики озер, в том числе режим водопользования и характер стратификации в момент отбора проб, приведены в табл. 1.

Для каждого озера были проведены следующие измерения. Прозрачность воды определяли с помощью диска Секки. Погружным зондом YSI Ехо (США) измеряли вертикальные профили температуры, удельной элек-

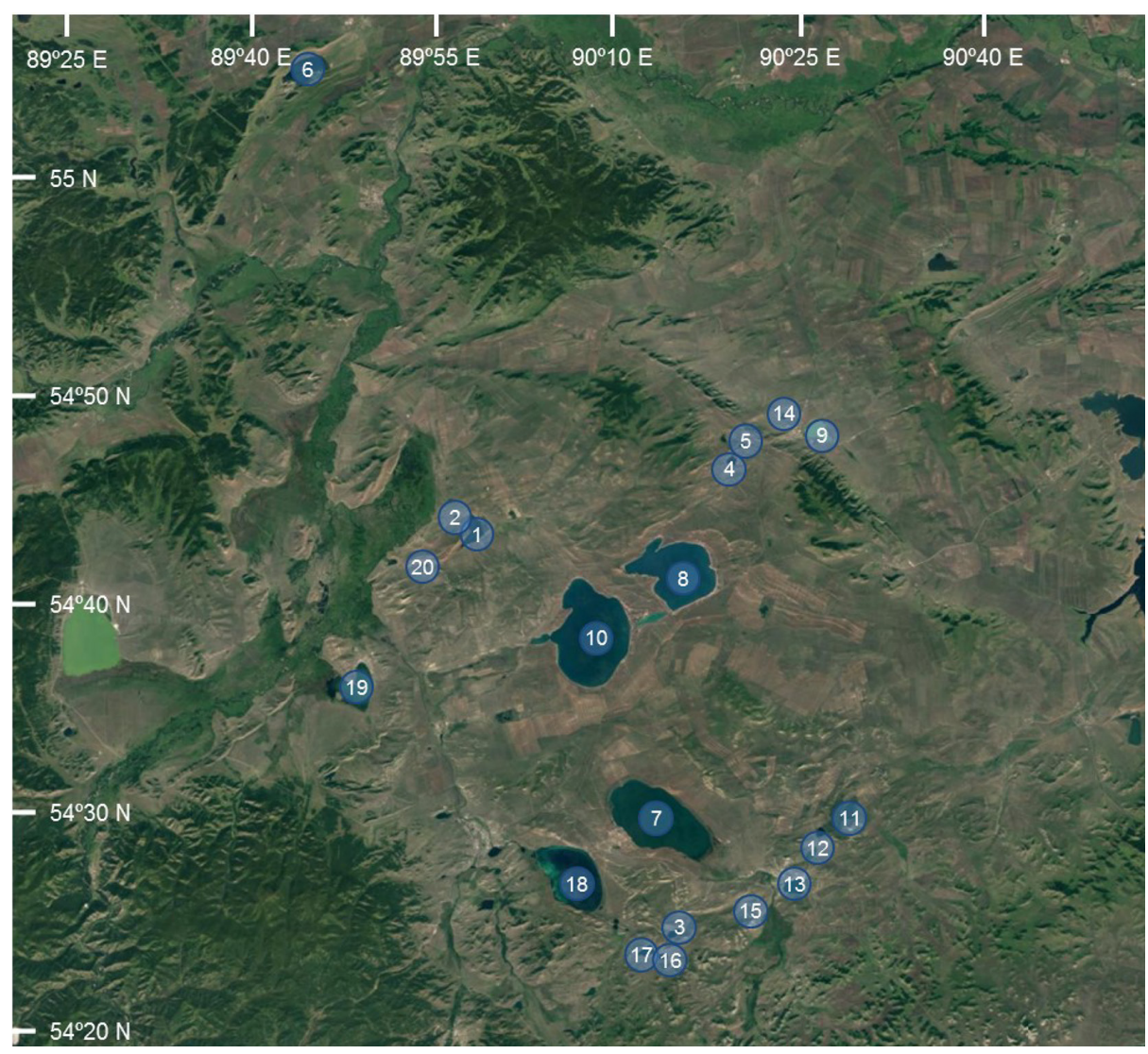

Рис. 1. Карта расположения озер, на которых проведены комплексные отборы проб. Нумерация озер соответствует перечислению озер в табл. 1. Карта в интерактивном формате доступна по ссылке https://www.google.com/maps/d/edit?mid=1f3Aw36YdUF2WIF226jeXgJ1zS3cvhs7k\&usp=sharing

Fig. 1. Map of the location of the lakes from which the samples were collected. Numbers corresponds to the list of lakes in Table 1. An interactive map is available at https://www.google.com/maps/d/edit?mid=1f3Aw36YdUF2 WIF226jeXgJ1zS3cvhs7k\&usp=sharing 


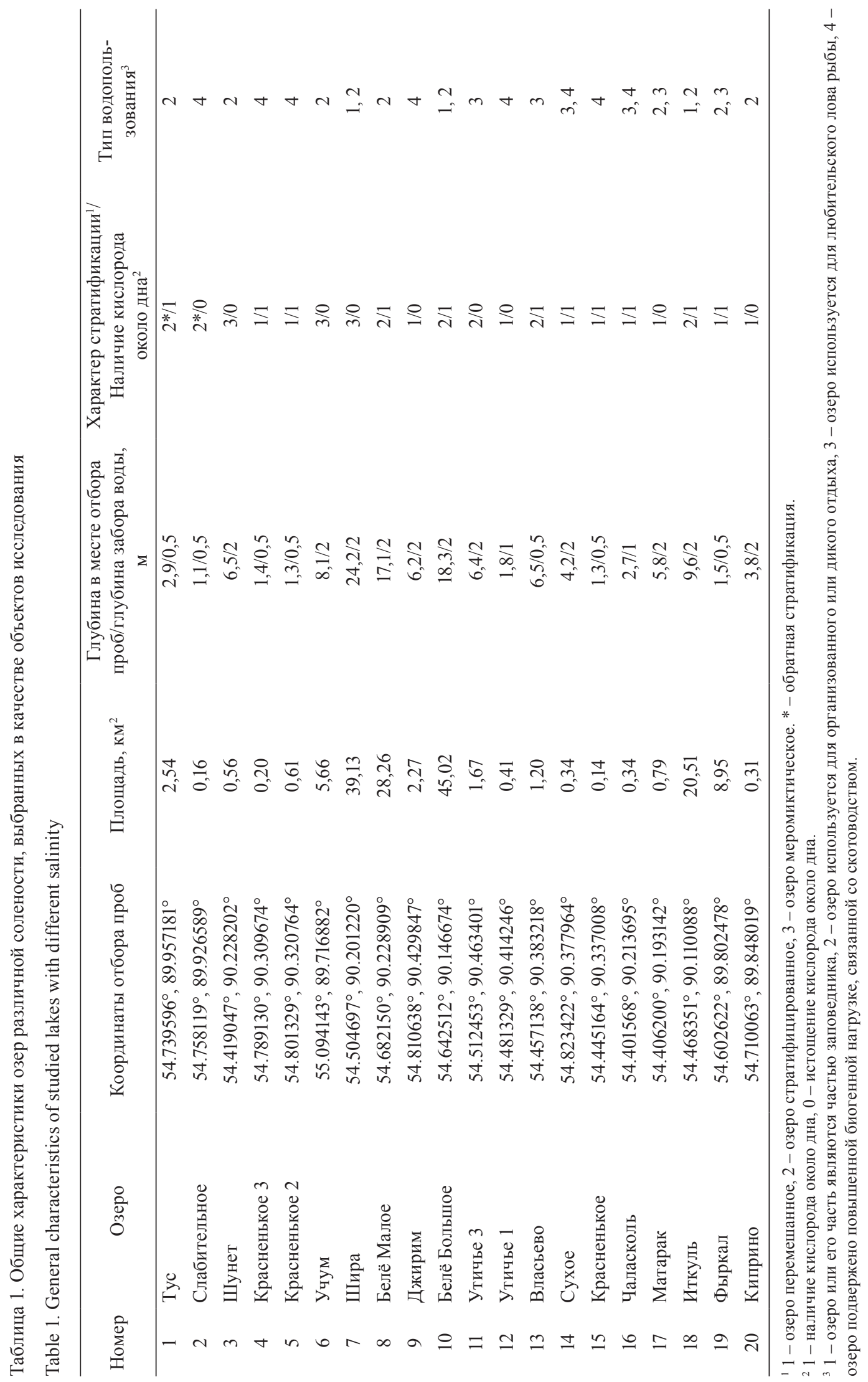


тропроводности, концентрации кислорода. В дальнейших анализах для классификации озер по категориям солености использовали значение общего содержания растворенных солей (г/л), рассчитанное в автоматическом режиме зондом на основе значений удельной электропроводности.

Погружным многоканальным флуориметром FluoroProbe (BBe, Германия) измеряли вертикальные профили распределения мутности, флуоресценции, связанной с возбуждением различных фотосинтетических пигментов. На основе этих измерений прибор автоматически рассчитывал общую концентрацию хлорофилла «а», а также доли флуоресцентного сигнала, связанного с присутствием в воде зеленых, диатомовых, криптофитовых водорослей и цианобактерий.

Интегральную пробу зоопланктона отбирали с помощью сети Джеди от дна до поверхности. Пробу фиксировали 70\%-ным этанолом. Оценку численности, измерение организмов и идентификацию до видов или родов проводили во всей пробе.

В каждом озере в эпилимнионе (глубина отбора проб отражена в табл. 1) с помощью вакуумного шлангового пробоотборника (погружной шланг с открытой воронкой диаметром 10 см) отбирали 5 л воды для следующих анализов.

Для анализа содержания органического углерода в сестоне предварительно профильтрованную через планктонную сеть с диаметром ячеи 115 мкм воду фильтровали через стекловолоконный фильтр GF/F (Whatman). Стекловолоконные фильтры предварительно прокаливали при температуре $400{ }^{\circ} \mathrm{C}$ в течение 4 ч. После фильтрации фильтры высушивали и хранили в темном сухом месте до проведения анализов. Содержание углерода измеряли с помощью элементного анализа- тора Flash-2000 (ThermoScientific, Германия) (Gladyshev et al., 2007).

Для гидрохимических анализов два литра воды, профильтрованной через планктонную сеть с диаметром ячеи 115 мкм, замораживали и позже анализировали в аналитической лаборатории Института биофизики СО РАН.

Содержание сульфатов определяли титриметрическим методом с хлоридом бария (РД 52.24.406-2018), хлоридов - аргентометрически (РД 52.24.407-2017). Аммонийный азот определяли по методу Несслера (Kalacheva et al., 2002; ПНД Ф 14.1:2:4.262-10), нитритный азот - с использованием реактива Грисса (РД 52.24.381-2017), нитратный азот переводили в нитритный редукцией на кадмиевой колонке (РД 52.24.380-2017), общий фосфор после минерализации и окисления персульфатом калия согласно (РД 52.24.3872019) определяли по реакции с молибдатом аммония и аскорбиновой кислотой с образованием молибденовой сини (РД 52.24.3822019) с последующим измерением оптической плотности на фотоэлектроколориметре КФК-2МП (Россия). Содержание карбонатов и гидрокарбонатов устанавливали титрованием $0,1 \mathrm{~N}$ или $0,01 \mathrm{~N}$ раствором $\mathrm{HCl}$ до $\mathrm{pH}$ $4,3, \mathrm{pH}$ оценивали с помощью стационарного pH метра PB-11 (Sartorius, Германия). Общее содержание элементов ( $\mathrm{K}, \mathrm{Na}, \mathrm{Ca}, \mathrm{Mg}, \mathrm{S}, \mathrm{B}$, $\mathrm{Ba}, \mathrm{Be}, \mathrm{Bi}, \mathrm{Ga}, \mathrm{Ni}, \mathrm{Pb}, \mathrm{Fe}, \mathrm{Mn}, \mathrm{Mo}, \mathrm{Cu}, \mathrm{Co}, \mathrm{Cd}$, $\mathrm{Cr}, \mathrm{Sr}, \mathrm{Se}, \mathrm{Sb}, \mathrm{As}, \mathrm{Al}, \mathrm{Li}, \mathrm{Ti}, \mathrm{Tl}, \mathrm{V}, \mathrm{Zn})$ определяли методом спектрометрии с индуктивносвязанной плазмой (ИСП) на спектрометре iCAP 6300 Duo (Thermo Scientific, Англия). Определение сухого остатка в воде проводили выпариванием при $105^{\circ} \mathrm{C}$, зольности - после прокаливания полученного осадка в муфельной печи при $450{ }^{\circ} \mathrm{C}$ до постоянной массы. Массу осадка определяли на аналитических весах Pioneer 214C (Ohaus, США) с точностью до 0,0001 г. 
Для анализа данных мы разделили все озера на четыре класса солености, совпадающие по общему содержанию растворенных солей с градацией озер по Зайцеву (Зайцев, 1986), однако с отличными для удобства использования названиями: пресные озера (соленость до 0,5 г/л), пресно-соленые озера (соленость 0,5-3,0 г/л), слабосоленые озера (соленость 3,0-10,0 г/л), соленые озера (соленость выше 10,0 г/л). Долговременное присутствие в пелагиали озера рыбы (1=да или $0=$ нет) определяли на основании литературных данных, разговоров с местными жителями, наличия на берегу озера рыбаков. Повышенную биогенную нагрузку, связанную с воздействием скота (1=да или $0=$ =ет), определяли по наличию на берегу озера выраженных мест водопоя скота, близости ферм или мест временного содержания животных.

Анализ влияния факторов солености (для четырех классов озер, разделенных по солености) и биогенной нагрузки (1 или 0$)$ на различные физико-химические и биологические характеристики озер проводили с помощью дисперсионного анализа. Взаимосвязи между различными характеристиками для всего массива данных устанавливали с помощью регрессионного анализа. Все расчеты осуществляли в программе STATISTICA 8.0.

\section{Результаты}

Физико-химические характеристики озер

Исследованные нами озера расположились в градиенте общего содержания растворенных солей (данные зонда YSI Ехо, далее будем использовать термин «соленость») от 0,1 до 31,5 г/л (табл. 2). В выбранных нами категориях солености пробы были взяты в трех пресных озерах (соленость до 0,5 г/л), четырех пресно-соленых (соленость 0,5-3,0 г/л), шести слабосоленых (соленость 3,0-10,0 г/л) и семи соленых озерах (соленость выше
10,0 г/л). Основными химическими элементами, определяющими солевой состав исследованных озер, были $\mathrm{Na}, \mathrm{Cl}, \mathrm{Mg}$, S. Содержание этих элементов, а также Са и К достоверно коррелировало с соленостью (табл. 2). На всем массиве данных зависимость содержания $\mathrm{HCO}_{3}$ и $\mathrm{CO}_{3}$ в воде от солености была недостоверной. При усреднении содержания карбонатов и бикарбонатов по категориям озер в пресных озерах концентрация $\mathrm{HCO}_{3}$ (147,8 мг/л) была достоверно ниже концентрации $\mathrm{HCO}_{3}$ в слабосоленых и соленых озерах (869,8 и 765,4 мл/г соответственно).

Озера существенно различались размером (диапазон площадей 0,14-45,02 км²) и глубиной в месте отбора проб (диапазон глубин 1,1-24,2 м), которая не всегда совпадала с максимальной глубиной. По типу стратификации в 10 озерах водная толща была перемешан до дна, семь озер были стратифицированы, три - известны нам на основании многолетних наблюдений как меромиктические. Тип стратификации зависел от двух основных параметров - глубины и солености озера. Для озер с соленостью до 10 г/л все водоемы глубиной до 6 м были перемешаны, глубже 6 м - стратифицированы. Для озер с соленостью выше 10 г/л характер стратификации был более сложный. Три озера в силу особенностей рельефа и ряда ранее описанных факторов меромиктические, в двух мелких озерах с соленостью до 20 г/л толща воды была перемешана. В двух мелких озерах соленостью выше 20 г/л наблюдалась обратная стратификация с резким повышением температуры и солености около дна (табл. 1).

Мы зафиксировали достаточно большой диапазон концентраций общего фосфора (от 0,004 до 1,203 мг/л) и форм азота в воде (от 0,032 до 1,447 мг/л) (табл. 3). Наименьшие концентрации биогенных элементов наблюдались в пресных озерах. Однако различия 


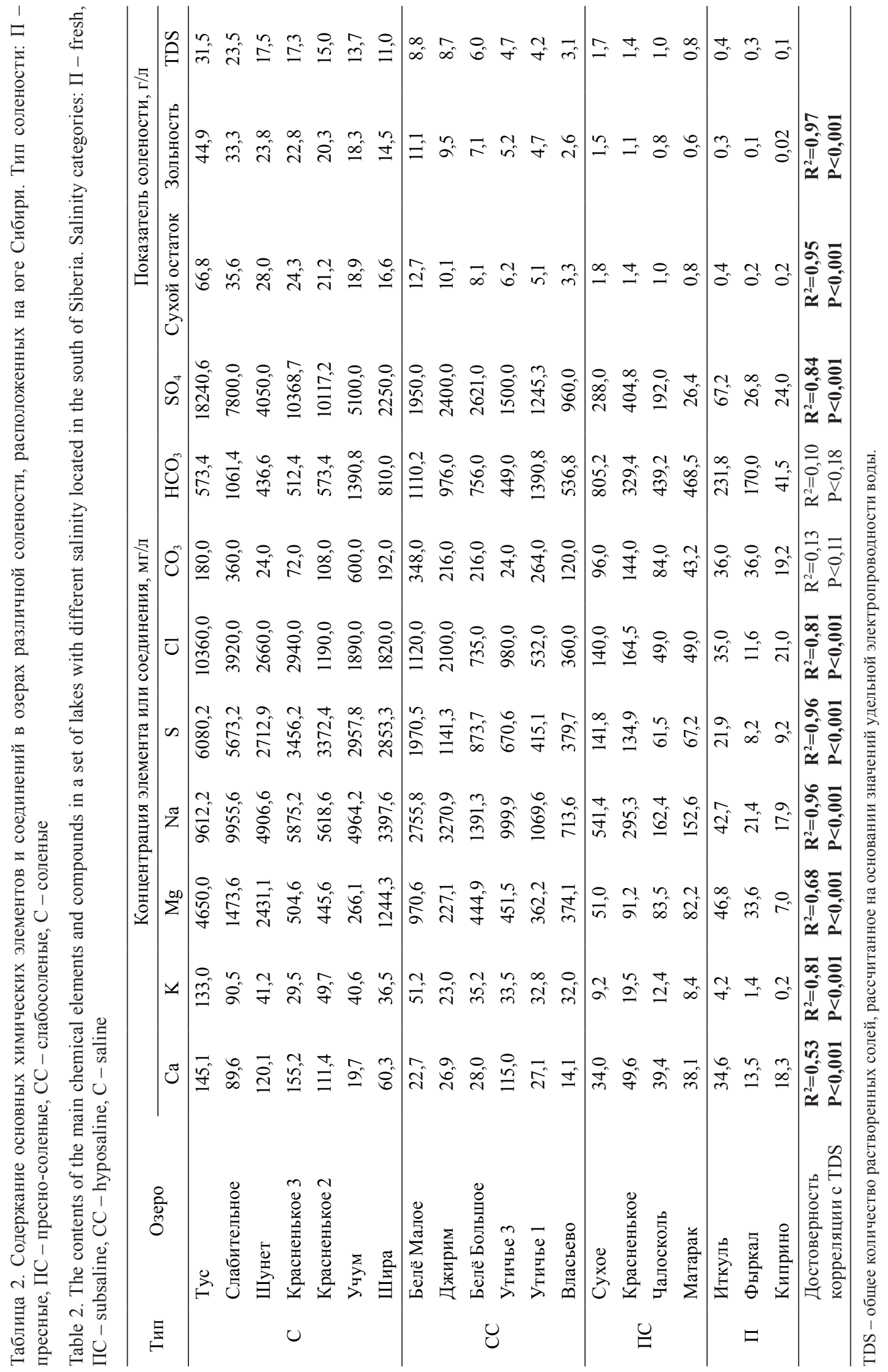


Таблица 3. Характеристики качества воды в 20 озерах различной солености в период летней стратификации Table 3. Characteristics of water quality in 20 lakes of different salinity during the summer stratification

\begin{tabular}{|c|c|c|c|c|c|}
\hline Озеро & $\mathrm{C}_{\text {seston }}, \mathrm{мГ/Л}$ & $\begin{array}{c}\text { Мутность, } \\
\text { NTU }\end{array}$ & $\begin{array}{c}\text { Прозрачность воды } \\
\text { по диску Секки, м }\end{array}$ & $\mathrm{P}_{\text {общ }}, \mathrm{Mг/л}$ & $\mathrm{N}_{\text {pact }}, \mathrm{MГ} / л$ \\
\hline Tyc & 0,95 & 2,74 & 2,7 & 0,138 & 0,461 \\
\hline Слабительное & 0,48 & 3,37 & 1,2 & 0,126 & 0,132 \\
\hline Шунет & 1,34 & 0,72 & 4,0 & 0,062 & 0,131 \\
\hline Красненькие 1 & 0,64 & 3,07 & 1,5 & 0,102 & 0,445 \\
\hline Красненькие 2 & 2,81 & 5,13 & 1,1 & 0,163 & 0,181 \\
\hline Учум & 0,40 & 1,51 & 4,0 & 0,071 & 0,278 \\
\hline Шира & 1,77 & 0,79 & 3,2 & 0,030 & 0,266 \\
\hline Белё Малое & 0,93 & 1,65 & 2,5 & 0,031 & 0,084 \\
\hline Джирим & 3,09 & 8,00 & 0,7 & 0,557 & 0,071 \\
\hline Белё Большое & 0,54 & 0,68 & 4,7 & 0,008 & 0,114 \\
\hline Утичье 3 & 0,35 & 0,36 & 4,5 & 0,020 & 0,215 \\
\hline Утичье 1 & 1,56 & 6,05 & 1,3 & 1,203 & 1,447 \\
\hline Власьево & 4,22 & 3,01 & 1,5 & 0,023 & 0,053 \\
\hline Cyxoe & 2,03 & 7,44 & 0,8 & 0,503 & 0,370 \\
\hline Красненькое & 0,70 & 1,35 & 1,5 & 0,318 & 0,292 \\
\hline Чаласколь & 3,67 & 10,89 & 0,7 & 0,043 & 0,210 \\
\hline Матарак & 2,04 & 2,57 & 1,6 & 0,017 & 0,095 \\
\hline Иткуль & 0,33 & 0,45 & 5,2 & 0,004 & 0,032 \\
\hline Фыркал & 0,69 & 0,86 & 1,7 & 0,009 & 0,123 \\
\hline Киприно & 0,81 & 0,98 & 2,9 & 0,008 & 0,078 \\
\hline
\end{tabular}

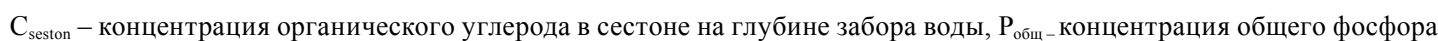
на глубине забора воды, определенная стандартным гидрохимическим методом, $\mathrm{N}_{\text {раст }}$ сумма растворенных форм азота $\mathrm{NH}_{4}, \mathrm{NO}_{2}$ и $\mathrm{NO}_{3}$ на глубине забора воды, определенных стандартными гидрохимическими методами. Глубина забора воды для каждого озера приведена в табл. 1.

в содержании биогенных элементов между группами озер, разделенных по солености, были недостоверными. Прозрачность воды по диску Секки (разброс значений от 0,7 до 5,2 м), мутность воды (разброс значений от 0,36 до 10,89 NTU) и общее количество взвешенного углерода (разброс значений от 0,33 до 4,22 мг/л) также не зависели от солености (табл. 3).

Повышенная биогенная нагрузка была значимым фактором, влияющим на концентрацию биогенных элементов, глубину видимости диска Секки и мутность воды (табл. 4). Общее содержание фосфора, прозрачность воды по диску Секки и мутность в водоемах, которые используются для водопоя или находятся вблизи мест массового выпаса скота, отличались от таковых в озерах, не используемых для этих целей ( $<<0,05)$. Для концентрации азота разница была недостоверна.

\section{Экологические характеристики озер}

Концентрация хлорофилла «а» в эпилимнионе озер варьировала в диапазоне от 1 до 63 мкг/л (рис. 2). В озерах, отнесенных к категории пресно-соленых, концентрация хлорофилла «а» $(28,9 \pm 13,7$ мкг/л) достоверно превышала таковую для остальных озер 
Таблица 4. Влияние повышенной биогенной нагрузки на ряд экосистемных параметров 20 озер юга Сибири

Table 4. The effect of increased nutrient load on a number of ecosystem parameters of 20 lakes in southern Siberia

\begin{tabular}{|c|c|c|c|c|c|}
\hline \multirow[t]{2}{*}{ Параметр } & \multicolumn{2}{|c|}{$\begin{array}{c}\text { Озеро не используется для } \\
\text { водопоя и не находится } \\
\text { в зоне выпаса животных }\end{array}$} & \multicolumn{2}{|c|}{$\begin{array}{c}\text { Озеро используется для } \\
\text { водопоя или находится } \\
\text { в зоне выпаса животных }\end{array}$} & \multirow[t]{2}{*}{$\begin{array}{c}\text { Достоверность } \\
\text { различия между } \\
\text { средними (one-way } \\
\text { ANOVA) }\end{array}$} \\
\hline & Mean & SE & Mean & SE & \\
\hline $\mathrm{P}_{\text {общ, }}, \mathrm{MГ} / л$ & 0,04 & 0,01 & 0,38 & 0,14 & $\mathbf{p}<0,05$ \\
\hline $\mathrm{N}_{\text {раст, }}$ мГ/л & 0,16 & 0,04 & 0,39 & 0,16 & $\mathrm{p}>0,05$ \\
\hline $\begin{array}{l}\text { Прозрачность воды } \\
\text { по диску Секки, м }\end{array}$ & 3,21 & 0,37 & 1,10 & 0,12 & $\mathbf{p}<0,05$ \\
\hline Мутность, NTU & 1,36 & 0,27 & 5,66 & 1,09 & $\mathbf{p}<0,05$ \\
\hline $\begin{array}{l}\text { Концентрация } \\
\text { хлорофилла «а», мкг/л }\end{array}$ & 4,94 & 0,97 & 18,45 & 7,72 & $\mathbf{p}<0,05$ \\
\hline $\begin{array}{l}\text { Биомасса } \\
\text { зоопланктона, г/м³ }\end{array}$ & 159,4 & 35,6 & 349,3 & 88,9 & $\mathbf{p}<0,05$ \\
\hline
\end{tabular}

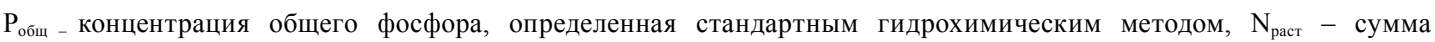
растворенных форм азота $\mathrm{NH}_{4}, \mathrm{NO}_{2}$ и $\mathrm{NO}_{3}$, определенных стандартными гидрохимическими методами, Меan среднее значение, SE - стандартная ошибка.

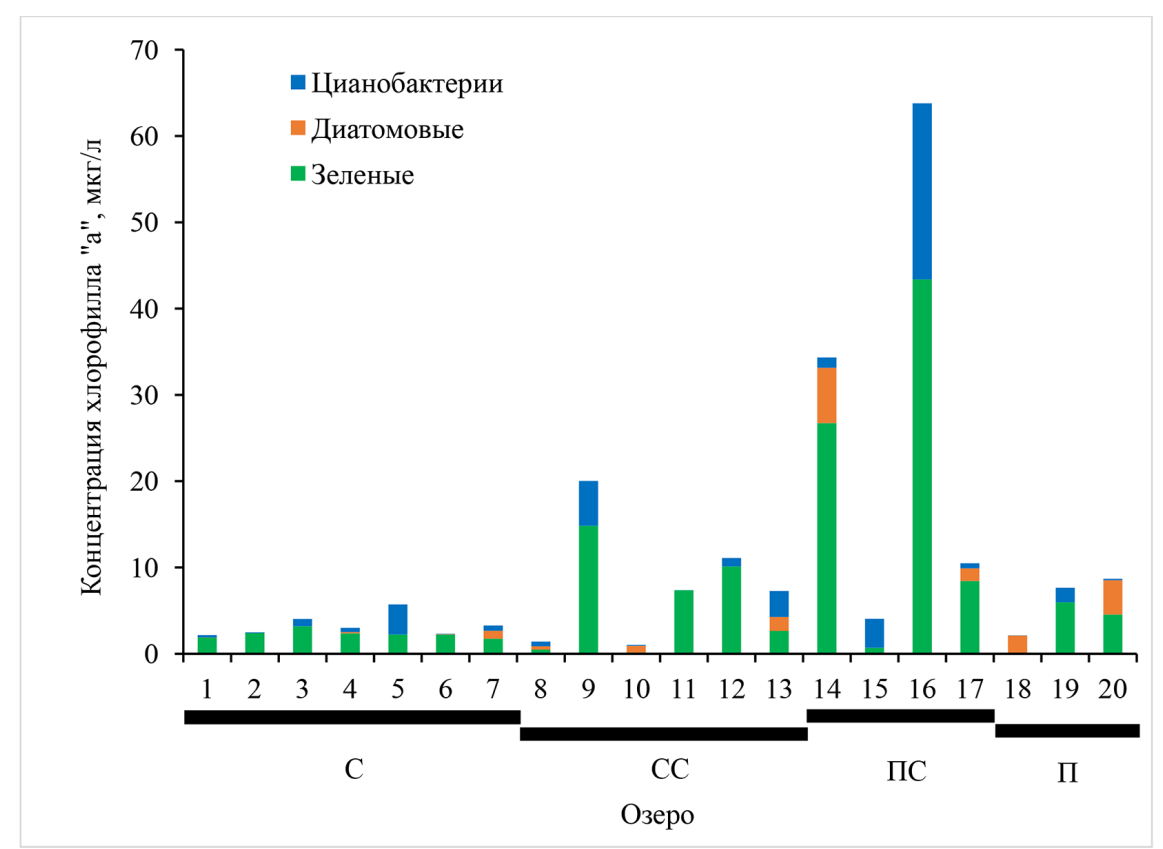

Рис. 2. Биомассы основных групп фитопланктона, выраженные в единицах хлорофилла «а», в исследованных озерах в период летней стратификации. Нумерация озер в градиенте солености от соленых к пресным, буквенные обозначения категорий солености соответствуют табл. 1. Биомассы приведены для глубины отбора проб воды (см. табл. 1)

Fig. 2. Biomasses of the main phytoplankton groups expressed in units of chlorophyll «a» in the studied lakes during the summer stratification. Lakes are numbered in the salinity gradient from saline to fresh, letter designations of salinity categories correspond to Table 1. Biomasses are presented for the depth of water sampling (see Table 1) 


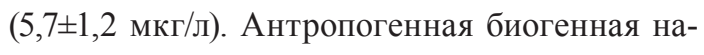
грузка была значимым фактором для концентрации хлорофилла «а» (табл. 4). Также были зафиксированы достоверные положительные корреляции между концентрацией хлорофилла «а» и концентрацией углерода в сестоне $(\mathrm{r}=0,59, \mathrm{p}<0,001)$, мутностью $(\mathrm{r}=0,84, \mathrm{p}<0,001)$, глубиной видимости диска Секки ( $\mathrm{r}=-0,48$, $\mathrm{p}=0,03)$ и биомассой зоопланктона $(\mathrm{r}=0,46$, $\mathrm{p}=0,04)$.

В составе фитопланктона большинства озер доминировали зеленые водоросли (рис. 2). Как и для общего содержания хлорофилла «а», концентрация хлорофилла зеленых водорослей в пресно-соленых озерах $(19,8 \pm 9,6$ мкг/л) превышала таковую в других озерах $(3,9 \pm 0,9$ мкг/л). Аналогично в озерах с антропогенной биогенной нагрузкой концентрация хлорофилла зеленых водорослей была выше (12,8 $\pm 5,4$ мкг/л), чем в озерах без таковой $(3,2 \pm 0,8$ мкг/л). Ни соленость, ни биогенная нагрузка не влияли на долю концентрации хлорофилла какого-либо из выделенных таксономических отделов (зеленые и диатомовые водоросли, цианобактерии) в общем составе фитопланктона (Tukey post-hoc test, $\mathrm{p}>0,05)$. Также мы не нашли корреляционных зависимостей между изменением биомассы зоопланктона и его отдельных групп (ветвистоусые и веслоногие ракообразные, коловратки) и изменением долей таксономических отделов в составе фитопланктона.

Биомасса зоопланктона варьировала в диапазоне от 32 до 720 г/м $\mathrm{M}^{3}$ (рис. 3). Биомасса зоопланктона, его отдельных таксономических групп (ветвистоусые, веслоногие, коловратки) или доли этих групп в биомассе не зависела от солености. Значимое воз-

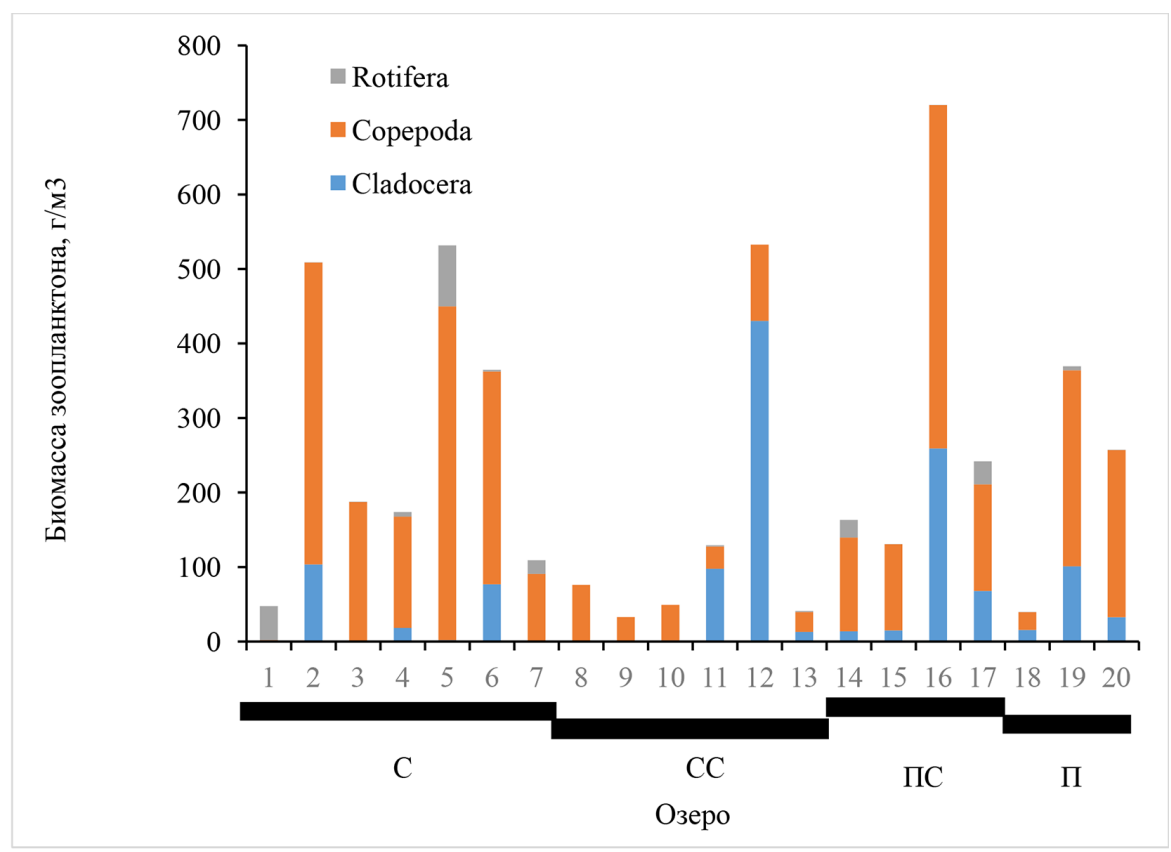

Рис. 3. Биомассы основных групп зоопланктона в пелагиали исследованных озер в период летней стратификации. Нумерация озер в градиенте солености от соленых к пресным и буквенные обозначения категорий солености соответствуют табл. 1

Fig. 3. Biomasses of the main groups of zooplankton in the pelagic zone of the studied lakes during the summer stratification. The numbering of lakes in the salinity gradient from saline to freshwater and the letter designations of the salinity categories correspond to Table 1 
действие на биомассу зоопланктона оказала биогенная нагрузка (табл. 4). Соленость достоверно влияла на видовой состав зоопланктона. С ростом солености падало как общее количество видов зоопланктона в пелагиали озер, так и количество видов ветвистоусых и веслоногих рачков (табл. 5).

С ростом солености в сообществе зоопланктона наблюдались определенные изменения. Мы рассмотрели их для ветвистоусых ракообразных, так как этой группе присущ неселективный тип питания, что часто является основанием считать их группой зоопланктона, способной контролировать развитие фитопланктона. В озерах с соленостью до 3 г/л сообщество ветвистоусых было достаточно разнообразным, с доминированием мелких Daphnia sp., Bosmina sp., других видов. В диапазоне соленостей 4-8 г/л мы зафиксировали присутствие в озерах крупно- го представителя Cladocera Daphnia magna. Далее в озерах с соленостью 13-23 г/л ветвистоусые были представителями рода Moina (рис. 4).

Доля озер, в которых зафиксировано присутствие рыб, снижалась с ростом солености, рыбы исчезали в озерах при солености выше 10 г/л (табл. 5). Достоверные эффекты двух структурирующих факторов, биогенной нагрузки и солености на компоненты и характеристики экосистем ряда озер представлены в виде наглядной схемы (рис. 5).

\section{Обсуждение}

Физико-химические характеристики озер

Изменчивость уровня воды и связанной с этим солености - естественная черта для многих соленых озер, расположенных в терминальных водных бассейнах. Так как уровень такого озера зависит от количества по-

Таблица 5. Влияние солености на общее количество видов зоопланктона в пелагиали озер и присутствие в экосистеме рыб для озер, разделенных на четыре класса солености: пресные озера (соленость до 0.5 г/л), пресно-соленые озера (соленость 1-3 г/л), слабосоленые озера (соленость 3-10 г/л), соленые озера (соленость выше 10 г/л)

Table 5. The effect of salinity on the number of zooplankton species in the pelagic zone and the presence of fish in lakes divided into 4 salinity categories: freshwater lakes (salinity up to $0.5 \mathrm{~g} / 1$ ), subsaline lakes (salinity $1-3 \mathrm{~g} / 1$ ), hyposaline lakes (salinity 3-10 g/l), saline lakes (salinity above $10 \mathrm{~g} / \mathrm{l}$ )

\begin{tabular}{|c|c|c|c|c|c|c|c|c|c|}
\hline \multirow{3}{*}{ Параметр } & \multicolumn{8}{|c|}{ Тип озера } & \multirow{3}{*}{$\begin{array}{c}\text { Результат } \\
\text { дисперсионного анализа } \\
\text { (ANOVA) }\end{array}$} \\
\hline & \multicolumn{2}{|c|}{ Пресные } & \multicolumn{2}{|c|}{$\begin{array}{l}\text { Пресно- } \\
\text { соленые }\end{array}$} & \multicolumn{2}{|c|}{$\begin{array}{l}\text { Слабо- } \\
\text { соленые }\end{array}$} & \multicolumn{2}{|c|}{ Соленые } & \\
\hline & Mean & $\mathrm{SE}$ & Mean & SE & Mean & SE & Mean & SE & \\
\hline $\begin{array}{l}\text { Общее количество } \\
\text { видов }\end{array}$ & 8,33 & 0,33 & 7,75 & 1,25 & 4,00 & 0,82 & 5,00 & 0,44 & $\begin{array}{l}\text { Current effect: } \\
F(3,16)=6,1, p=0,006\end{array}$ \\
\hline $\begin{array}{l}\text { Количество видов } \\
\text { Cladocera }\end{array}$ & 4,33 & 0,33 & 3,25 & 0,48 & 1,17 & 0,31 & 1,00 & 0,31 & $\begin{array}{l}\text { Current effect: } \\
F(3,16)=17,6, p=0,00003\end{array}$ \\
\hline $\begin{array}{l}\text { Количество видов } \\
\text { Copepoda }\end{array}$ & 2,00 & & 2,50 & 0,29 & 1,83 & 0,31 & 1,00 & 0,22 & $\begin{array}{l}\text { Current effect: } \\
F(3,16)=5,8, p=0,007\end{array}$ \\
\hline $\begin{array}{l}\text { Количество видов } \\
\text { Rotifera }\end{array}$ & 1,67 & 0,33 & 2,00 & 0,71 & 1,00 & 0,52 & 2,86 & 0,40 & $\begin{array}{l}\text { Current effect: } \\
F(3,16)=2,8, p=0,07\end{array}$ \\
\hline \multicolumn{10}{|c|}{ Доля озер, в которых обитает рыба, \% } \\
\hline Присутствие рыб & \multicolumn{2}{|c|}{100} & \multicolumn{2}{|c|}{75} & \multicolumn{2}{|c|}{50} & \multicolumn{2}{|c|}{0} & $\begin{array}{l}\text { Current effect: } \\
F(3,16)=6,4, p=0,005\end{array}$ \\
\hline
\end{tabular}

Mean - среднее значение, SE - стандартная ошибка. 


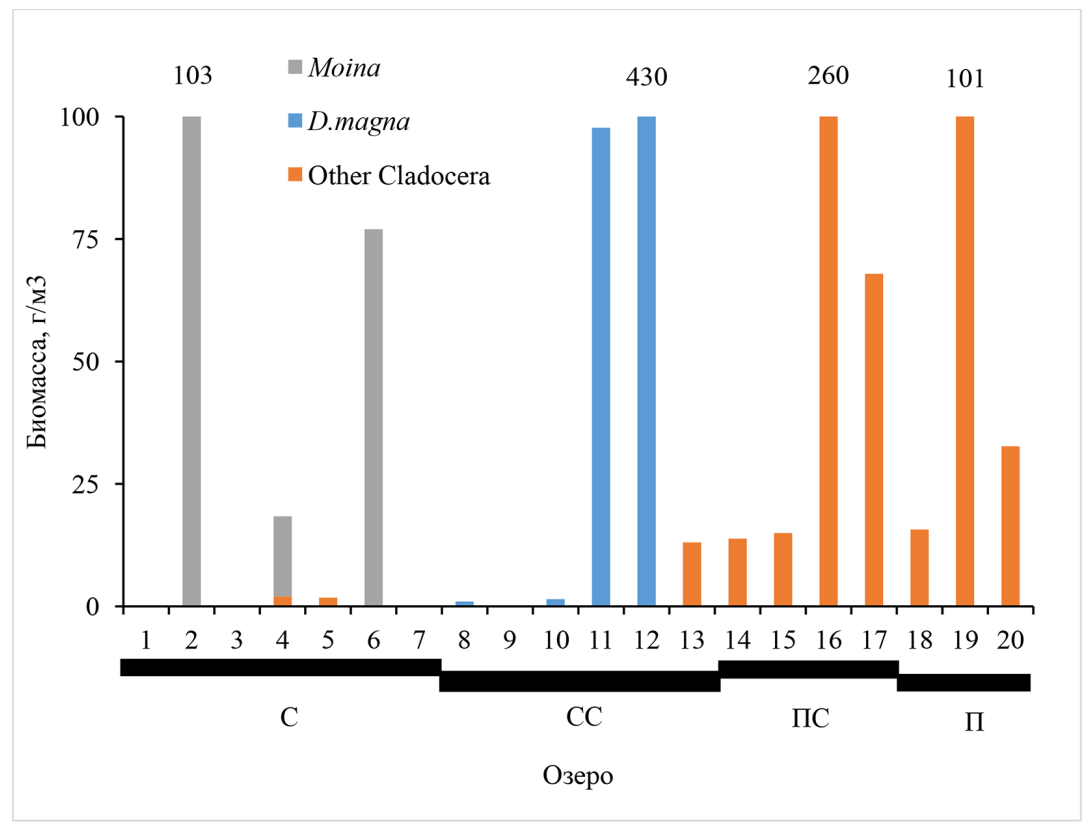

Рис. 4. Биомассы доминирующих в ряду различающихся соленостью озер юга Сибири ветвистоусых ракообразных. Нумерация озер приведена в соответствии с использованной в табл. 1. Цифры над столбцами обозначают биомассу животных в соответствующем озере, выходящую за пределы использованного масштаба оси Y

Fig. 4. Biomass of cladocerans dominating in a series of lakes differing in salinity in southern Siberia. The lakes are numbered as in the Table 1 . The numbers above the columns represent the biomass of animals in the corresponding lake outside the Y-axis scale used

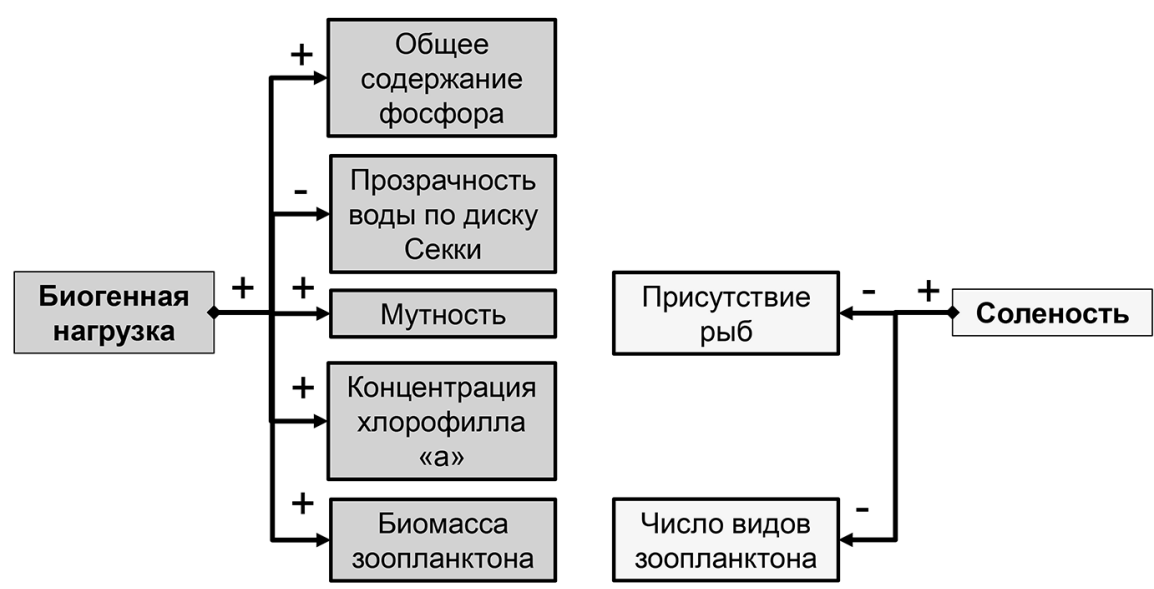

Рис. 5. Схематичное изображение воздействия на экосистемы озер юга Сибири двух структурирующих факторов: биогенной нагрузки и солености. Статистическая значимость действия соответствующего фактора и значения экосистемных параметров представлены в табл. 4 и 5. + - между фактором и параметром наблюдается прямая взаимосвязь,-- между фактором и параметром наблюдается обратная взаимосвязь

Fig. 5. Schematic representation of the impact of two structuring factors on the ecosystems of lakes in southern Siberia: nutrient load and salinity. The statistical significance of the effect of the relevant factor and the values of ecosystem parameters are presented in Tables 4 and 5. +- a positive correlation between the factor and the parameter,-- a negative correlation between the factor and the parameter

$$
-146-
$$


ступающей в водоем воды и интенсивности испарения с поверхности, любые изменения соотношения скоростей двух этих процессов критичны для экосистемы озера. В настоящее время в исследованных нами озерах наблюдается рост уровня воды и падение солености (Rogozin et al., 2017a; Zadereev et al., 2020). Наши данные показывают, что соленость практически во всех исследованных озерах стала ниже по сравнению с данными, представленными в работе почти 20-летней давности (Parnachev and Degermendzhy, 2002). Учитывая, что многие экологические и экономические решения принимаются на основании информации о солености того или иного водоема, периодическая ревизия информации о текущем состоянии водоема крайне необходима. Так, во многих документах, предназначенных для массового использования, озеро Тус упоминается как местное Мертвое море (например, электронный ресурс http:/gpx.su/place/34-ozero-tus.html; дата доступа 28.09.2020), тогда как текущий уровень воды в озере и содержание солей приближаются к границе гиперсоленых озер, после которой возможны существенные перестройки в экосистеме озера.

Мы не зафиксировали влияния солености ни на один из параметров, которые косвенно можно считать связанными с качеством воды (прозрачность воды по диску Секки и мутность воды, общее содержание фосфора и растворенных форм азота). В то же время на эти параметры существенное воздействие оказал достаточно условный параметр «наличие повышенной биогенной нагрузки, связанной с воздействием скота». С одной стороны, мы принимали решение об отнесении озера к категории испытывающего биогенную нагрузку на основании визуальных и логических заключений (наличие выраженных мест водопоя, наличия ферм или загонов в непосред- ственной близости от озера). С другой стороны, этот параметр был достоверно значимым для содержания в воде основного биогенного элемента фосфора. То есть наш алгоритм выделения озер с повышенной биогенной нагрузкой оказался верным. В целом данный результат не должен вызывать удивление. Известно, что в озерах, расположенных вблизи мест выпаса и водопоя скота, повышается содержание фосфора и падает качество воды (например, Sigua et al., 2006). Высокое содержание фосфора закономерно приводило к уменьшению прозрачности и повышению мутности воды, что в целом соответствует надежно установленной взаимосвязи между содержанием фосфора в водоеме и качеством воды (например, Oglesby and Schaffner, 1978).

Интересно посмотреть на характеристики озер, используемых для выпаса скота. Преимущественно это небольшие и мелкие водоемы. Исключения составляют, с одной стороны, относительно крупное озеро Джирим, которое по результатам измерений стало одним из самых мутных и загрязненных фосфором озер, и малые озера пресное Киприно и соленое Шунет, которые используются в рекреационных целях и входят в число наиболее чистых озер. Можно предположить, что в целом малые озера не рассматриваются как объекты рекреационной или заповедной ценности и вовлекаются в хозяйственный оборот как объекты инфраструктуры скотоводства за исключением редких случаев, когда в силу особенностей рельефа (озеро Шунет) или чистоты озера (озеро Киприно) они становятся объектами рекреации.

\section{Экологические характеристики озер}

Анализ данных позволил выявить две основных закономерности: влияние биогенной нагрузки (bottom-up-контроль) на увеличение биомассы звеньев трофической цепи 
и снижение показателей прозрачности воды и влияние солености на трофическую цепь, приводящее к исчезновению рыбы и смене доминирующих видов зоопланктона. При этом соленость не влияла на биомассу звеньев трофической цепи.

Действие солености на структуру трофической цепи в целом соответствует результатам, полученным на подобных системах озер разной солености. В озерах Тибета критическая соленость для присутствия рыб в экосистеме (10 г/л) в точности совпала с нашими наблюдениями (Gutierrez et al., 2018). В нашем случае в литературе присутствуют данные об обнаружении в более соленом озере Шира карася, однако рыба наблюдалась лишь в месте впадения в озеро пресной реки Coн (Rogozin et al., 2011), где соленость падает ниже критического уровня.

С точки зрения формирующего эффекта солености на структуру сообщества зоопланктона можно сказать, что наши данные уточняют полученные ранее результаты других исследователей. Lin et al. (2017) представил в своей работе концептуальную схему смены видов зоопланктона в градиенте солености озер Тибета. Стоит отметить, что данная схема существенно упрощена. Так, практически во всех наших озерах при всех соленостях существенную долю биомассы зоопланктона составляли представители веслоногих ракообразных (Copepoda). Для озер с соленостью до 3 г/л, как и на представленной концептуальной диаграмме, действительно характерно разнообразное сообщество относительно мелких видов ветвистоусых (Cladocera) и веслоногих ракообразных. Крупные дафнии (Daphnia magna) в наших озерах наблюдаются в диапазоне соленостей от 4 до практически 9 г/л. При этом дафнии замечены и в озерах, где присутствует рыба. Далее, с ростом солености, с исчезновением и дафний и рыб в сообществе зоопланктона вновь появляются мелкие, толерантные к солености виды Cladocera (представители рода Moina), массово наблюдаются Copepoda и коловратки (Rotifera). Следующей, в каком-то смысле классической стадией для сообществ зоопланктона соленых озер можно считать доминирование жаброногих рачков Artemia (Anufriieva, Shadrin, 2020) (в нашем случае в озере Тус).

Стоит отметить два условных артефакта, которые могут быть предметом отдельного исследования. Наличие крупной Daphnia magna в озере Малое Белё, крупном водоеме с соленостью, близкой к 9 г/л, и населенного рыбой, можно считать одним из предельных случаев с точки зрения толерантности к солености у этого вида (Schuytema et al., 1997). Отсутствие ветвистоусых ракообразных и рыб и в целом крайне низкое видовое разнообразие зоопланктона в озере Джирим с более низкой, чем в озере Малое Белё, соленостью. По всей видимости, это связано с солевым составом озера Джирим, в частности с более высоким содержанием натрия и хлора, которые превышают таковые даже для озера Шира. Можно предположить, что по своему солевому составу и концентрациям солей Джирим при текущем уровне воды попадает в диапазон критической солености с минимально возможным набором видов, способных жить в этом водоеме (Khlebovich, 1969).

Другим важным неучтенным фактором может быть наличие в экосистеме озера крупного бенто-пелагического вида Gammarus lacustris. В нашем случае мы не учитывали присутствие и биомассу амфипод, как и других крупных беспозвоночных, например личинок насекомых, в озерах. Известно, что в близко расположенных соленых озерах Шира и Шунет Gammarus обитает в том числе и в пелагиали, не являясь, как это считалась ранее, бентосным видом (Zadereev et 
al., 2010), и в его рацион, по данным жирнокислотного анализа, могут входить представители зоопланктона (Makhutova et al., 2018). Экспериментальные и полевые исследования показали, что гаммариды активно потребляют планктонных ракообразных и могут угнетать их популяции (Shadrin et al., 2020). Таким образом, наличие и биомасса амфипод - важные, структурирующие сообщество зоопланктона факторы, не учтенные в данном исследовании.

Ряд исследованных нами озер покрывает относительно небольшой диапазон встречающихся в природных водоемах соленостей. Действительно, при рассмотрении озер с соленостью 100 г/л и выше закономерности по снижению видового состава и биомассы звеньев трофической цепи с ростом солености могут быть более очевидны (Golubkov et al., 2018; Shadrin, Anufriieva, 2020). Однако основные перестройки в структуре трофической цепи, связанные с исчезновением рыб и сменой доминирующих групп зоопланктона с различным типом питания, способным быть ключевым для селективного выедания и контроля сообщества фитопланктона (Sommer, Sommer, 2006), происходят в диапазоне соленостей ниже 50 г/л. Это означает, что детальное рассмотрение ряда подобных озер, в частности выполненное нами, представляет существенный интерес.

Наши результаты показывают, что для рассмотренных озер в середине летнего сезона биомассы фито- и зоопланктона в первую очередь контролировались биогенной нагрузкой (bottom-up контроль). При этом мы фактически не смогли зафиксировать каскадных эффектов (top-down-контроль). С одной стороны, соленость структурировала трофическую сеть - с ее ростом в озерах исчезала рыба, уменьшалось количество видов зоопланктона и происходили закономерные изменения в видовом составе зоопланктона. С другой стороны, мы не обнаружили какихлибо значимых отличий между сообществами фитопланктона в разных озерах, которые можно было бы связать с видовым составом зоопланктона. Также наличие рыб не оказывало значимого воздействия на биомассу зоопланктона.

Для интерпретации полученных результатов с определенными допущениями можно использовать концептуальную модель сезонного развития планктона (PEG model, Sommer et al., 1986). Так, после весеннего развития фитопланктона для озер характерен локальный минимум концентрации фитопланктона (фаза чистой воды), который в зависимости от трофического статуса озера наблюдается либо в начале, либо ближе к середине лета. В нашем случае для ряда озер стоит ожидать наступления этой фазы в середине летнего сезона, что совпадает со временем отбора проб. В этом случае, по крайней мере для озер с низким содержанием фосфора, биомассы фито- и зоопланктона будут находиться в локальных минимуме и максимуме, что приведет к отсутствию прямой зависимости между этими экосистемными параметрами.

Однако подобные рассуждения достаточно спекулятивны. В целом, о наличии каскадных эффектов в экосистемах следует судить не по данным одномоментного отбора проб, а на основании оценок динамических характеристик взаимодействующих популяций (McCauley, Murdoch, 1987). Применительно к природным сообществам проверить характер взаимосвязей можно в лабораторных или контролируемых экспериментах либо сравнив результаты отборов проб в разное время, что позволит проследить за динамикой развития взаимодействующих сообществ. Мы ожидаем, что обнаружить каскадные эффекты и изменения в составе фитопланктона, 
связанные с трансформацией сообщества зоопланктона под действием солености, можно на основании отборов проб в выбранной линейке озер в разные фазы развития планктонных сообществ, начиная с условного весеннего старта и заканчивая осенним предзимним периодом снижения активности зоопланктона из-за низких температур.

\section{Заключение}

На собранном массиве данных мы показали, что с ростом солености в диапазоне от пресных вод до вод с содержанием растворенных солей более 30 г/л в озерных экосистемах уменьшается количество видов зоопланктона и сложность трофической цепи; изменения в видовом составе и структуре трофической цепи происходят при критических уровнях солености. Однако нам не удалось зафиксировать каскадных эффектов, а именно показать, что смена функциональных групп зоопланктона, различающихся типом питания, с изменением солености приводит к изменениям в видовом составе фитопланктона. В то же время данное исследование представляет отдельный интерес в силу нескольких важных причин. Во-первых, в нем выполнена важная ревизия современного состояния ряда озер юга Сибири, расположенных в градиенте солености. Обновленные данные по солености озер, основным физико-химическим характеристикам могут служить реперной точкой для дальнейших исследований озер региона. Во-вторых, применительно к исследованию трофических сетей крайне важно, что выбранный ряд озер отличается «мелким шагом» по солености. Различия в солености между озерами невелики, что позволяет с детальным разрешением посмотреть на критический диапазон солености. Именно в этом диапазоне из экосистем озер исчезают рыбы, а в сообществе зоопланктона происходят ключевые перестройки, связанные со сменой видов, обладающих различными способностями контролировать обилие и видовой состав фитопланктона. Наши результаты показывают, что в выбранном ряду озер наблюдаются ключевые, структурирующие трофическую сеть эффекты bottom-up-контроля и солености. Это означает, что данный ряд озер можно рассматривать в качестве условной модельной системы, детальные исследования которой могут принести значимые для современной водной экологии результаты.

\section{Список литературы / References}

Басков Е. А., Зуев А. В., Гирфанова О. М. (1972) Минеральные воды. Гидрогеология СССР. T. XVIII. Красноярский край и Тувинская АССР. Сидоренко А. В. (ред.) М., Недра, с. 306-326 [Baskov E. A., Zuev A.V., Girfanova O.M. (1972) Mineral waters. Hydrogeology of the USSR. Volume XVIII. Krasnoyarsk Territory and Tuva Autonomous Soviet Socialist Republic. Sidorenko A. V. (ed.) Moscow, Nedra, p. 306-326 (in Russian)]

Гидроминеральные ресурсы района озера Шира (1959) T. 1. Отчет о работах 1957-1958 г2. Москва, 394 с. [Hydromineral resources of the Lake Shira region (1959) Volume 1. Report on the works of 1957-1958. Moscow, 394 p. (in Russian)]

Гусева Н.В., Копылова Ю.Г., Хващевская А.А., Сметанина И.В. (2012) Химический состав соленых озер Северо-Минусинской котловины, Хакасия. Известия Томского политехнического университета. Инжиниринг георесурсов, 321(1): 163-168 [Guseva N.V., Kopylova Yu.G., Hvashchevskaya A. A., Smetanina I. V. (2012) Chemical composition of salt lakes in the North Minusinsk depression, Khakassia. Bulletin of the Tomsk Polytechnic University. Geo Assets 
Engineering [Izvestiya Tomskogo politekhnicheskogo universiteta. Inzhiniring georesursov], 321(1): 163-168 (in Russian)]

Зайцев И.К. (1986) Гидрогеохимия СССР. Недра, Ленинград, 239 с. [Zaitsev I.K. (1986) Gidrogeokhimiya SSSR. Nedra, Nauka, 239 p. (in Russian)]

Кусковский В. С., Кривошеев А. С. (1989) Минеральные озера Сибири. Новосибирск, Наука, 200 c. [Kuskovskij V.S., Krivosheev A. S. (1989) Mineral lakes of Siberia. Novosibirsk, Nauka, 200 p. (in Russian)]

ПНД Ф 14.1:2:4.262-10 (2010) Методика измерений массовой концентрации ионов аммония в питьевых, поверхностных (в том числе морских) и сточных водах фотометрическим методом с реактивом Несслера. Москва, 22 с. [14.1:2:4.262-10 (2010) Method for measuring the mass concentration of ammonium ions in drinking, surface (including sea) and run-off waters by the photometric method with Nessler's reagent. Moscow, 22 p. (in Russian)]

РД 52.24.380-2017 (2017) Массовая конџентрация нитратного азота в водах. Методика измерений фотометрическим методом с реактивом Грисса после восстановления в кадмиевом редукторе. Ростов-на-Дону, 30 с. [52.24.380-2017 (2017) Mass concentration of nitrate nitrogen in waters. Measurement technique by photometric method with Griss reagent after reduction in a cadmium reducer. Rostov-on-Don, 30 p. (in Russian)]

РД 52.24.381-2017 (2017) Массовая кониентраиия нитритного азота в водах. Методика измерений фотометрическим методом с реактивом Грисса. Ростов-на-Дону, 21 с. [РД 52.24.3812017 (2017) Mass concentration of nitrite nitrogen in waters. Photometric measurement method with Griss reagent. Rostov-on-Don, 21 p. (in Russian)]

РД 52.24.382-2019 (2019) Массовая кониентрация фосфатного фосфора в водах. Методика измерений фотометрическим методом. Ростов-на-Дону, 25 с. [52.24.382-2019 (2019) Mass concentration of phosphate phosphorus in waters. Photometric measurement technique. Rostov-onDon, 25 p. (in Russian)]

РД 52.24.387-2019 (2019) Массовая концентрачия фосфора общего и фосфора валового в водах. Методика измерений фотометрическим методом после окисления персульфатом калия. Ростов-на-Дону, 20 с. [52.24.387-2019 (2019) Mass concentration of total phosphorus and total phosphorus in waters. Photometric measurement technique after oxidation with potassium persulfate. Rostov-on-Don, 20 p. (in Russian)]

РД 52.24.406-2018 (2018) Массовая концентрация сульфатов в водах. Методика измерений титриметрическим методом с хлоридом бария. Ростов-на-Дону, https://files.stroyinf.ru/ Data2/1/4293734/4293734198.htm [52.24.406-2018 (2018) Mass concentration of sulfates in waters. Measurement technique by titrimetric method with barium chloride. Rostov-on-Don, https://files. stroyinf.ru/Data2/1/4293734/4293734198.htm (in Russian)]

РД 52.24.407-2017 (2017) Массовая кониентрачия хлоридов в водах. Методика измерений аргентометрическим методом. Ростов-на-Дону, 22 с. [52.24.407-2017 (2017) Mass concentration of chlorides in waters. Measurement technique by argentometric method. Rostov-on-Don, 22 p. (in Russian)]

Afonina E. Yu., Tashlykova N.A. (2020) Fluctuations in plankton community structure of endorheic soda lakes of southeastern Transbaikalia (Russia). Hydrobiologia, 847(6): 13831398 
Anufriieva E., Shadrin N. (2020) The long-term changes in plankton composition: Is Bay Sivash transforming back into one of the world's largest habitats of Artemia sp. (Crustacea, Anostraca)? Aquaculture Research, 51(1): 341-350

Comín F. A., Rodó X., Comín P. (1992) Lake Gallocanta (Aragón, NE Spain): a paradigm of fluctuations at different scales of time. Limnetica, 8: 79-86

Degermendzhy A.G., Z Zadereev E. S., $\quad$ Rogozin D. Y., $\quad$ Prokopkin I. G., $\quad$ Barkhatov Y.V., Tolomeev A.P., Khromechek E. B., Janse J.H., Mooij W.M., Gulati R. D. (2010) Vertical stratification of physical, chemical and biological components in two saline lakes Shira and Shunet (South Siberia, Russia). Aquatic Ecology, 44(3): 619-632

Gladyshev M. I., Sushchik N. N., Kolmakova A. A., Kalachova G. S., Kravchuk E. S., Ivanova E. A., Makhutova O.N. (2007) Seasonal correlations of elemental and omega-3 PUFA composition of seston and dominant phytoplankton species in a eutrophic Siberian Reservoir. Aquatic Ecology, 41(1): 9-23

Golubkov S. M., Shadrin N.V., Golubkov M.S., Balushkina E.V., Litvinchuk L.F. (2018) Food chains and their dynamics in ecosystems of shallow lakes with different water salinities. Russian Journal of Ecology, 49(5): 442-448

Gozlan R.E., Karimov B.K., Zadereev E., Kuznetsova D., Brucet S. (2019) Status, trends, and future dynamics of freshwater ecosystems in Europe and Central Asia. Inland Waters, 9(1): 78-94

Gutierrez M.F., Tavşanoğlu Ü.N., Vidal N., Yu J., Teixeira-de Mello F., Çakiroglu A.I., He H., Liu Z., Jeppesen E. (2018) Salinity shapes zooplankton communities and functional diversity and has complex effects on size structure in lakes. Hydrobiologia, 813(1): 237-255

Jeppesen E., Nõges P., Davidson T.A., Haberman J., Nõges T., Blank K., Lauridsen T.L., Søndergaard M., Sayer C., Laugaste R., Johansson L. S., Bjerring R., Amsinck S. L. (2011) Zooplankton as indicators in lakes - a plea for including zooplankton in the ecological quality assessment of lakes according to the European Water Framework Directive (WFD). Hydrobiologia, 676(1): 279-297

Kalacheva G. S., Gubanov V. G., Gribovskaya I. V., Gladchenko I. A., Zinenko G. K., Savitsky S. V. (2002) Chemical analysis of Lake Shira water (1997-2000). Aquatic Ecology, 36: 123-141

Khlebovich V.V. (1969) Aspects of animal evolution related to critical salinity and internal state. Marine Biology, 2(4): 338-345

Langbein W.B. (1961) Salinity and hydrology of closed lakes: A study of the long-term balance between input and loss of salts in closed lakes. Washington, US Government Printing Office, $20 \mathrm{p}$.

Lin Q., Xu L., Hou J., Liu Z., Jeppesen E., Han B.-P. (2017) Responses of trophic structure and zooplankton community to salinity and temperature in Tibetan Lakes: Implication for the effect of climate warming. Water Research, 124: 618-629

Makhutova O.N., Shulepina S.P., Sharapova T.A., Kolmakova A.A., Glushchenko L.A., Kravchuk E.S., Gladyshev M.I. (2018) Intraspecies variability of fatty acid content and composition of a cosmopolitan benthic invertebrate, Gammarus lacustris. Inland Waters, 8(3): 356-367

McCauley E., Murdoch W.W. (1987) Cyclic and stable populations: plankton as paradigm. American Naturalist, 129(1): 97-121

Micklin P. (2007) The Aral Sea disaster. Annual Review of Earth and Planetary Sciences, 35: 47-72

Oglesby R. T., Schaffner W. R. (1978) Phosphorus loadings to lakes and some of their responses.

Part 2. Regression models of summer phytoplankton standing crops, winter total $\mathrm{P}$, and transparency of New York lakes with known phosphorus loadings. Limnology and Oceanography, 23(1): 135-145 
Parnachev V.P., Degermendzhy A.G. (2002) Geographical, geological and hydrochemical distribution of saline lakes in Khakasia, Southern Siberia. Aquatic Ecology, 36(2): 107-122

Rogozin D., Zadereev E., Prokopkin I., Tolomeev A., Barkhatov Y., Khromechek E., Degermendzhi N., Drobotov A., Degermendzhi A. (2017a) Comparative study of the stability of stratification and the food web structure in the meromictic lakes Shira and Shunet (South Siberia, Russia). Ecology of meromictic lakes. Springer, Cham, p. 89-124

Rogozin D. Y., Pulyayevskaya M.V., Zuev I.V., Makhutova O.N., Degermendzhi A.G. (2011) Growth, diet and fatty acid composition of Gibel carp Carassius gibelio in Lake Shira, a brackish water body in Southern Siberia. Journal of Siberian Federal University. Biology, 4(1): 86-103

Rogozin D.Y., $\quad$ Tarnovsky M.O., $\quad$ Belolipetskii V.M., $\quad$ Zykov V.V., $\quad$ Zadereev E.S., Tolomeev A.P., Drobotov A.V., Barkhatov Y.V., Gaevsky N.A., Gorbaneva T.B., Kolmakova A.A., Degermendzhi A. G. (2017b) Disturbance of meromixis in saline Lake Shira (Siberia, Russia): possible reasons and ecosystem response. Limnologica, 66: 12-23

Rogozin D. Y., Zykov V.V., Ivanova E.A., Anufrieva T. N., Barkhatov Y.V., Khromechek E.B., Botvich I. Y. (2018) Meromixis and seasonal dynamics of vertical structure of lake Uchum (South Siberia). Contemporary Problems of Ecology, 11(2): 195-206

Schuytema G. S., Nebeker A.V., Stutzman T.W. (1997) Salinity tolerance of Daphnia magna and potential use for estuarine sediment toxicity tests. Archives of Environmental Contamination and Toxicology, 33(2): 194-198

Shadrin N. V., Anufriieva E. V. (2020) Structure and trophic relations in hypersaline environments. Biology Bulletin Reviews, 10: 48-56

Sigua G. C., Williams M. J., Coleman S. W., Starks R. (2006) Nitrogen and phosphorus status of soils and trophic state of lakes associated with forage-based beef cattle operations in Florida. Journal of Environmental Quality, 35(1): 240-252

Shadrin N., Yakovenko V., Anufriieva E. (2020) Gammarus aequicauda and Moina salina in the Crimean saline waters: New experimental and field data on their trophic relation. Aquaculture Research, 51(8): 3091-3099

Sommer U., Gliwicz Z. M., Lampert W., Duncan A. (1986) The PEG-model of seasonal succession of planktonic events in fresh waters. Archiv fur Hydrobiologie, 106(4): 433-471

Sommer U., Sommer F. (2006) Cladocerans versus copepods: the cause of contrasting top-down controls on freshwater and marine phytoplankton. Oecologia, 147(2): 183-194

Williams W.D. (2002) Environmental threats to salt lakes and the likely status of inland saline ecosystems in 2025. Environmental Conservation, 29(2): 154-167

Zadereev E., Lipka O., Karimov B., Krylenko M., Elias V., Pinto I. S., Alizade V., Anker Y., Feest A., Kuznetsova D., Mader A., Salimov R., Fischer M. (2020) Overview of past, current and future ecosystem and biodiversity trends of inland saline lakes of Europe and Central Asia. Inland Waters, 10(4): 438-452

Zadereev E. S., Tolomeyev A.P., Drobotov A. V., Emeliyanova A. Y., Gubanov M. V. (2010) The vertical distribution and abundance of Gammarus lacustris in the pelagic zone of the meromictic lakes Shira and Shunet (Khakassia, Russia). Aquatic Ecology, 44(3): 531-539 